УДК 349.2

DOI https://doi.org/10.32837/yuv.v0i2.2174

\author{
В. Альошин, \\ orcid.org / 0000-0002-1925-8337 \\ аспірант кафедри цивільно-правових дисциплін і трудового права \\ імені професора О. І. Процевського \\ Харківського національного педагогічного університету імені Г. С. Сковороди
}

\title{
ПОНЯТТЯ СОЦАЛЬНОГО ЗАХИСТУ СПІВРОБІТНИКІВ ПРАВООХОРОННИХ ОРГАНІВ
}

\begin{abstract}
Актуальність питань соціального захисту обумовлена об'єктивною потребою суспільства в ефективній системі забезпечення правопорядку, здатної гарантувати захист особистості, суспільства і держави від злочинних посягань. Крім того, соціальний захист працівників правоохоронних органів $є$ однією 3 умов антикорупційної політики держави. Правоохоронні органи відіграють важливу роль в механізмі сучасної держави. Від ефективності їх діяльності багато в чому залежать рівень законності і правопорядку в країні, безпека громадян, ступінь захисту їх прав та законних інтересів. У свою чергу, ефективність діяльності правоохоронних органів перебуває в прямій залежності від рівня соціального захисту їх працівників і членів сімей співробітників. Однак як показує статистика, в даний час рівень соціального захисту працівників правоохоронних органів та членів ї сімей ще далекий від необхідного.
\end{abstract}

Постановка мети. Специфіка правоохоронної служби, в тому числі обмеження на службі, вимагає забезпечення співробітників не тільки грошовим утриманням. Важливе значення мають охорона здоров'я, в тому числі медична допомога, медикаментозне забезпечення, санаторно-курортне лікування та відпочинок працівників і членів їх сімей, утримання дітей співробітників в дитячих дошкільних установах, соціально-по- бутове забезпечення співробітників та їх сімей, пенсійне забезпечення, інші заходи соціальної захисту. Все сказане вище зумовило актуальність теми цієї статті і визначило ї̈ вибір.

Питаннями дослідження соціального захисту різних категорій працівників займалося багато вчених-правників, таких як: M.I. Ануфрієв, Н.Б. Болотіна, В.С. Венедіктов, P.I. Кондрат'єв, О.В. Лавриненко, Л.I. Лазор, В.Т. Маляренко, К.Ю. Мельник, І.М. Сирота, Г.І. Чанишева, О.Г. Чутчева, В.Ш. Шайхатдинов, В.I. Щербина. Також здійснено чимало дисертаційних досліджень на цю тему. Однак внаслідок недостатньої вивченості, залишається актуальною потреба дослідження правового регулювання соціального забезпечення працівників правоохоронних органів.

Виклад основного матеріалу. Соціальний захист співробітників правоохоронних органів $є$ складовою частиною соціального захисту державних службовців та соціального захисту населення у цілому. Виходячи 3 того, що соціальний захист $є$ родовим поняттям, вона включає в себе діяльність держави, органів місцевого самоврядування, організацій 3 забезпечення умов для нормальної життєдіяльності населення [1].

Широкий круг мір, у такій якості, охоплює соціальний захист населення, спрямованих, з одного боку, на ефективне здійснення громадянами своїх службових обов'язків, 
та на забезпечення їх існування 3 іншого. Однобічну спрямованість має іх соціальний захист у випадках, коли громадяни ще або вже не здійснюють свою трудову діяльність. Такі сфери, як забезпечення сім’і, матері та дитини, охорона здоров'я, регулювання трудових відносин (включно з оплатою праці та охороною праці), соціальне обслуговування, пенсійне забезпечення, забезпечення грошовою допомогою та інші входять до соціального захисту населення. Нормами конституційного, адміністративного, цивільного, фінансового, трудового права та права соціального забезпечення здійснюється правове регулювання соціального захисту. Як структурний елемент соціального захисту населення має більш вузьку сферу діяльності соціальний захист державних службовців, ніж соціальний захист населення.

Суб'єктивним складом зумовлюються іï рамки - державними службовцями та членами їхніх сімей, також особливостями правового статусу службовців, тобто їх службою. На дві складові частини може бути розділений соціальний захист державних службовців:

1) безпосередньо спрямовані міри на забезпечення державних службовців;

2) міри, спрямовані на забезпечення членів сімей державних службовців.

Соціальний захист співробітників правоохоронних органів як частина системи соціального захисту державних службовців характеризується такими основними ознаками.

Перше - вона включає відносини між співробітниками правоохоронних органів (а у деяких випадках й (або) членами їхніх сімей), з одного боку, та державними органами, органами місцевого самоврядування, установами, організаціями - з іншого.

Друге - нормальні умови службової діяльності співробітників правоохоронних органів покликані забезпечувати соціальний захист, а також компенсацію підвищених психологічних та фізичних навантажень, негативних наслідків настання соціальних випадків та службових обмежень, які призводять до необхідності соціального захисту.

трете - соціальний захист здійснюється за рахунок специфічних фінансових джерел.

Четверте - соціальний захист здійснюється на підставі відповідних нормативно-правових актів.

П’яте - грошові виплати, натуральне забезпечення, послуги виступають мірами соціального захисту [2].

Розпочатий в Україні на конституційних засадах процес державотворення потребує чіткого визначення в ньому місця та ролі правоохоронних органів. Очевидно, що розкрити вказане поняття неможливо без з'ясування того, хто саме відноситься до категорії «працівники правоохоронних органів». До цієї статті Інститутом законодавства Верховної Ради України було надано коментар. До правоохоронних органів автори відносять: СБУ, внутрішні війська МВС України, міліцію та деякі державні структури, статус яких визначається підзаконними актами [4, с. 58-61]. Офіційний термін правоохоронні органи дається в Законі України «Про державний захист працівників суду і правоохоронних органів» від 23 грудня 1993 року № 3781 [5]. Згідно зі ст. 2 правоохоронні органи, органи прокуратури, внутрішніх справ, служби безпеки, Військової служби правопорядку у Збройних Силах України, митні органи, органи охорони державного кордону, органи державної податкової служби, органи і установи виконання покарань, слідчі ізолятори, органи державного фінансового контролю, рибоохорони, державної лісової охорони, інші органи, які здійснюють правозастосовні або правоохоронні функціі. Вважаємо, що вказівка в Законі «інші органи, які здійснюють правозастосовні або правоохоронні функції» не сприяє ефек- 
тивній реалізації положень вказаного закону через те, що містить розмиту диспозицію, нечітко зрозуміло, які саме ще органи підпадають під визначення системи правоохоронних органів і до яких суб'єктів системи цю норму необхідно застосовувати. Слід звернути увагу, що, відповідно до вказаного Закону захисту підлягають працівники суду і правоохоронних органів, зазначених у частині першій цього пункту, а також співробітники кадрового складу розвідувальних органів України, працівники Антимонопольного комітету України та уповноважені особи Національної комісії 3 цінних паперів та фондового ринку, які беруть безпосередню участь у розгляді судових справ у всіх інстанціях; кримінальному провадженні та провадженні у справах про адміністративні правопорушення; оперативно-розшуковій та розвідувальній діяльності; охороні громадського порядку і громадської безпеки; виконанні вироків, рішень, ухвал і постанов судів, постанов органів, що здійснюють оперативно-розшукову діяльність, досудове розслідування, та прокурорів; які беруть участь у контролі за переміщенням людей, транспортних засобів, товарів та інших предметів чи речовин через державний і митний кордон України та нагляді і контролі за виконанням законів. Однак вирішення цієї проблеми пов'язано з певними труднощами, зумовленими, в першу чергу, відсутністю законодавчого визначення поняття правоохоронного органу та ознак, за яких той чи інший новостворений підрозділ міг би належати до цієї категоpii. 3 огляду на це необхідно на законодавчому рівні чітко визначити систему правоохоронних органів України виходячи зі змісту правоохоронної діяльності й головних ознак правоохоронних органів.

Для вирішення цього питання необхідно виходити з функцій, які виконують відповідні державні органи:
1) забезпечення безпеки, законності та правопорядку;

2) боротьби зі злочинністю;

3) захист прав та свобод людини та громадянина.

Особливими видами безпеки є державна, економічна та інформаційна безпека.

До об'єктів державної безпеки відносять фізичних осіб (особи, які заміщають державні посади), а також саму державу, території, які знаходяться під охороною, державні кордони, ядерні матеріали і т.д. Виходячи 3 вище вказаних об'єктів, державну безпеку забезпечують органи служби безпеки.

Економічна безпека забезпечується правоохоронними органами, митною службою, службою безпеки, службою 3 контролю обігом наркотиків.

В окремих наукових працях розрізняють саме правоохоронні органи та спеціальні служби. При цьому під спеціальними службами розуміють державні органи, створені і діючі з метою захисту національних інтересів і безпеки як на території країни, так і за іï межами.

Встановивши круг правоохоронних органів, потрібно з'ясувати, хто 3 ї співробітників відноситься до кола осіб, які обіймають посади правоохоронної служби.

Єдиного реєстру державних посад правоохоронної служби в даний час не існує. Тому ці посади необхідно виявляти з різних джерел. При цьому слід враховувати не тільки посади правоохоронної служби, але і спеціальні звання, оскільки для правоохоронної служби характерно більш істотний вплив спеціальних звань, обсяг прав на окремі пільги, доплати залежить не тільки від займаної посади, а й від спеціального звання. Встановивши склад правоохоронних органів та склад співробітників правоохоронних органів, необхідно виявити ті органи і установи, які безпосередньо надають заходи соціального захисту. Надання заходів соціального захисту співробітників правоохорон- 
них органів і членам їх сімей здійснюється в основному відповідними підрозділами та установами правоохоронних органів, а не органами соціального захисту населення та установами Пенсійного фонду, як це має місце у відношенні осіб, що працюють (працювали) за трудовим договором. Тільки деякі заходи соціального захисту співробітників правоохоронних органів i членам їх сімей можуть надаватися в загальному порядку. Крім того, пенсійне забезпечення співробітників правоохоронних органів може здійснюватися установами Пенсійного фонду, якщо ці співробітники до призначення їм пенсій згідно із законом були звільнені зі служби, не мають необхідної вислуги років або позбавлені спеціальних звань до звернення за пенсією.

Друга ознака соціального захисту співробітників правоохоронних органів охоплює три взаємопов'язаних напрямки.

Перше стосується прав співробітників і обов'язків правоохоронних органів, які пов'язані з безпосереднім змістом службових правовідносин і охоплюються поняттям «умови служби». Це статутні права співробітників, закріплені в основоположних нормативних правових актах про відповідні правоохоронні служби, а також у контрактах між співробітниками і цими службами.

Другий напрямок охоплює виплати і компенсації звільненим співробітникам (одноразова і щомісячна допомога, збереження соціально-побутового і медичного обслуговування та ін.).

Третій напрям включає надання заходів соціального захисту у зв'язку з настанням соціальних випадків, які спричинили або могли спричинити несприятливі наслідки. Йдеться про застосування вироблених у науці соціальних випадків до соціального захисту співробітників правоохоронних органів. До випадків біологічної групи відносяться хвороба внаслідок загального захворювання або побуто- вої травми, вагітність і пологи, інвалідність внаслідок загального захворювання або побутової травми, смерть внаслідок цих же причин. Водночас до співробітників правоохоронних органів не може бути застосований такий соціальний випадок біологічного характеру, як старість, тому, що служба в цих органах обмежена віковою межею, яка не можна вважати старістю. Крім того, співробітникам правоохоронних органів призначається не пенсія за старістю, а пенсія за вислугу років. Нарешті, тут має місце втрата годувальника - співробітника правоохоронного органу внаслідок загального захворювання або побутової травми.

Другу групу соціальних випадків становлять випадки виробничого (службового) характеру. Тут $є$ військова травма, захворювання, отримане під час проходження служби. Їхніми наслідками можуть бути тимчасова непрацездатність, інвалідність, смерть. Сюди так само слід, на наш погляд, додати і вислугу років як самостійну підставу соціального захисту співробітників правоохоронних органів. Нарешті, від смерті внаслідок військової травми або захворювання, отриманого під час проходження служби, йде втрата годувальника як підстава соціального захисту членів сімей співробітників правоохоронних органів.

Третя група соціальних випадків включає життєві обставини демографічного характеру. Це наявність дітей у сім’і, багатодітність, неповнота сім’і, сирітство.

Нарешті, четверта група охоплює такі випадки економічного характеру, як інфляція, а так само малозабезпеченість. Не застосовуються практично до співробітників правоохоронних органів такі випадки, як безробіття (четверта група), самотність (третя група) і ін.

Дуже істотним є те, що наступ соціальних випадків, як правило, тягне за собою несприятливі наслідки у вигляді втрати доходу, його зниження, або 
виникнення підвищених витрат. Нерідко соціальні випадки супроводжуються так само необхідністю тимчасового або постійного припинення служби. Тому мета соціального захисту - запобігти, пом'якшити або усунути несприятливі наслідки настання соціальних випадків, а так само створити нормальні умови для виконання співробітниками правоохоронних органів своїх службових обов'язків.

Наступна ознака соціального захисту співробітників правоохоронних органів стосується фінансових джерел соціального захисту. Основним фінансовим джерелом є бюджет. Однак у разі заподіяння шкоди життю або здоров'ю працівників правоохоронних органів їх соціальний захист здійснюється за рахунок коштів обов'язкового державного страхування. Черговою ознакою соціального захисту співробітників правоохоронних органів є ii нормативна основа. Соціальний захист співробітників правоохоронних органів здійснюється відповідно до нормативних правових актів різної юридичної сили та галузевої належності.

Нарешті, остання ознака соціального захисту співробітників правоохоронних органів наявність особливих заходів соціального захисту. Вище вже зазначалося, що соціальний захист здійснюється у вигляді грошових виплат, натурального забезпечення і послуг. До числа грошових виплат відносяться грошове забезпечення, пенсії, допомоги, компенсації, щомісячна грошова виплата. До натурального забезпечення слід віднести майнове забезпечення, продовольче забезпечення, медикаментозне забезпечення. Послуги включають медичне забезпечення, набір соціальних послуг, соціальне обслуговування і т.д.

3 урахуванням викладеного вище можна сформулювати таке визначення поняття соціального захисту співробітників правоохоронних органів. Соціальний захист співробітників правоохоронних органів - цее система правових відносин, які виникають між співробітниками правоохоронних органів і правоохоронними органами, іншими суб'єктами права, з приводу надання співробітникам $i$ (або) членам їх сімей на основі нормативних правових актів $i$ з коштів бюджету, а також інших джерел грошових виплат, натурального забезпечення $i$ послуг при настанні соціальних випадків, що тягнуть за собою необхідність ї соціального захисту, з метою забезпечення нормальних умов службової діяльності співробітників, а також компенсаціі підвищених психологічних і фізичних навантажень, службових обмежень $і$ несприятливих наслідків настання соціальних випадків.

Визначивши поняття соціального захисту співробітників правоохоронних органів, слід вивчити іï співвідношення із суміжними поняттями, такими як «соціальне забезпечення», «соціальні гарантії», «правові гарантії. Під соціальним забезпеченням розуміється система суспільних відносин, що складаються між громадянами та органами держави, місцевого самоврядування, організаціями із приводу надання громадянам з соціальних джерел і на основі законодавства медичної допомоги, пенсій, допомоги та інших видів забезпечення при настанні соціальних випадків, що тягнуть за собою втрату або зниження доходу, підвищені витрати, малозабезпеченість, з метою попередження, пом'якшення або усунення несприятливих наслідків настання цих випадків [7]. Як видно, соціальне забезпечення $€$ частиною соціального захисту. Воно надається переважно тоді, коли співробітники правоохоронних органів тимчасово (через хворобу, травми, догляду за хворим членом сім’і, відпустки у зв'язку з вагітністю та пологами, по догляду за дитиною і т.д.) не можуть виконувати службові обов'язки (медична допомога, допомоги по тимчасової непрацездатності, по вагітності та пологах, 
по догляду за дитиною та ін.), або припинили службові відносини за вислугою років, інвалідності, у зв'язку зі смертю (пенсійне забезпечення, соціальна підтримка, соціальне обслуговування і ін.). У той же час в соціальне забезпечення не входять такі заходи соціального захисту, як грошове забезпечення, майнове та продовольче забезпечення, відшкодування шкоди, заподіяної життю або здоров'ю працівників, забезпечення їх житловими приміщеннями і т.д.. У нормативних правових актах і науковій літературі нерідко вживається словосполучення «соціальні гарантії» [8]. Це має місце як в найменуванні деяких нормативних правових актів, так і в їх утриманні. Однак легального визначення поняття соціальних гарантій досі немає. У той же час $є$ нагальна необхідність дослідити це поняття. У теорії права під гарантіями розуміється система умов, засобів і способів, що забезпечують всім і кожному рівні правові можливості для виявлення, придбання і реалізації своїх прав і свобод. Таке поняття $€$ загальним і охоплює всі гарантії, незалежно від їх змісту. У комплексі вони створюють можливості для здійснення громадянами своїх прав і виконання обов'язків. У той же час $€$ необхідність в класифікації гарантій 3 тих чи інших підстав. Якщо взяти за основу різні аспекти стану громадянина в суспільстві (економічний, політичний, соціальний, правовий), то можна виділити відповідні їм гарантії.

Так, розрізняються економічні, соціальні і правові гарантії. У зв'язку 3 цим не можна погодиться 3 авторами, які виділяють або тільки юридичні та організаційні гарантії, або соціально-економічні, політичні та юридичні гарантії, або правові, соціально-економічні, організаційно-управлінські та морально-психологічні гарантіі. Немає підстав, на наш погляд, вважати соціальними всі гарантії, закріплені в законі. Зміст гарантій змінюється залежно від конкретного статусу громадянина.
Так, для осіб, які працюють за трудовим договором, гарантії встановлені у розділі VIII КЗпП України, для безробітних громадян - у ст. 5 Закону України «Про зайнятість населення» i т.д. Особливої уваги потребує питання про соціальні гарантії особам, що заміщає державні посади державних службовців.

Ряд соціальних гарантій суддям встановлені законом України «Про судоустрій і статус суддів», ВВР, 2016, № 31, ст. 545. По-перше, в цьому законі йдеться про гарантії соціального захисту, що також підтверджує правильність нашої позиції. По-друге, в законі дається перелік цих гарантій (заробітна плата, щомісячне довічне утримання, компенсація витрат за наймом (піднайму) житлових приміщень, знижка в оплаті жилої площі, комунальних послуг, санаторно-курортне лікування та т. д.). Єдині гарантії поширюються і на державних службовців. У комплексі гарантії забезпечують економічний, правовий і соціальний захист державних службовців, ї ефективну службову діяльність. За допомогою економічних гарантій створюються фінансові та матеріальні умови державної служби. Правові гарантії забезпечують захищеність державного службовця шляхом регламентації просування по службі, перепідготовки та підвищення кваліфікації, захисту службовця і членів його сім’і від насильства, погроз, інших неправомірних дій, при звільненні зі служби та ін. Що стосується соціальних гарантій, то основою для дослідження їх поняття служить Конституції України. У ній закріплено, що в Україні охороняють працю і здоров'я людей, встановлюються гарантований мінімальний розмір оплати праці, забезпечується державна підтримка сім’і, материнства, батьківства і дитинства, інвалідів та людей похилого віку, розвивається система соціальних служб, встановлюються державні пенсіі, соціальні виплати та інші гарантії соціального захисту. 
Як видно, Конституція України пов'язує соціальні гарантії із соціальним захистом населення. Значить соціальні гарантії можна вважати заходами (видами) соціального захисту громадян, в тому числі і державних службовців. У Конституції України перераховані основні соціальні гарантіï. Однак їх перелік не $є$ вичерпним. Крім того, вони стосуються непрацездатних громадян і сімей з дітьми. Це не означає, однак, що соціальні гарантії не можуть поширюватися на працездатних громадян, у тому числі державних службовців, що проходять правоохоронну службу.

Оскільки соціальне забезпечення являє собою частину соціального захисту населення, соціальні гарантії можуть виступати як види соціального забезпечення. У зв'язку із цим виникає питання про те, які соціальні гарантії слід розглядати як види соціального забезпечення, а які - як види соціального захисту населення? Для відповіді на це питання слід, перш за все, виявити вичерпний перелік соціальних гарантій для співробітників правоохоронних органів. Перелік соціальних гарантій для всіх державних службовців містився в законі України від 10.12.2015 р. «Про державну службу». Він включав: 1) грошове утримання та інші виплати; 2) медичне обслуговування; 3) пенсійне забезпечення державного службовця і членів його сім’і; 4) обов'язкове соціальне страхування на випадок заподіяння шкоди здоров'ю та майну державного службовця у зв'язку з виконанням посадових обов'язків; 5) обов'язкове державне соціальне страхування на випадок захворювання службовця або втрати ним працездатності в період проходження державної служби; 6) надання житлової площі. Цей перелік не можна вважати вичерпним, у ньому відсутні деякі інші соціальні гарантії. Більш того, в законі вказувалося, що законами можуть бути передбачені й інші гарантії для державного службовця.
Тому норми про соціальні гарантії працівників правоохоронних органів слід шукати в актах про окремі види правоохоронної служби. Соціальні гарантії слід відрізняти від правових гарантій. Як соціальні гарантії $€$ видами соціального захисту співробітників правоохоронних органів, так і правові гарантії являють собою види їх правового захисту. Під правовим захистом розуміється система заходів правового і організаційного характеру, що гарантується і реалізується державою, для забезпечення кваліфікованого виконання співробітниками своїх службових обов'язків. Із цього визначення, проте, складно виявити будь-які конкретні правові гарантії. Звісно ж, що всі вони стосуються умов служби: регулювання службового часу і часу відпочинку, відпусток, просування по службі, заохочень і дисциплінарних стягнень, звільнення зі служби і т.д.

Усі ці заходи є самостійними по відношенню до заходів соціального захисту співробітників правоохоронних органів. Тому не можна погодиться 3 авторами, які вважають за можливе об'єднати соціальний і правовий захист. Більш правильною видається позиція тих вчених, на думку яких, зміст правового захисту та соціального захисту різниться. Дуже складним є питання про галузеву приналежність правових норм, що регулюють соціальний захист співробітників правоохоронних органів і відповідних правовідносин. При здійсненні соціального захисту співробітників виникає кілька груп правовідносин. По-перше, це правовідносини щодо забезпечення належних умов служби (з охорони праці, грошового забезпечення, майнового та продовольчого забезпечення, соціально-побутового забезпечення та медичного обслуговування). Спільними для всіх цих правовідносин є їх тісний зв'язок зі службовим правоохоронним правовідносинами. Однак галузева приналежність цих правовідносин неоднакова. 
Так, правовідносини з охорони праці та грошового забезпечення співробітників знаходяться під впливом адміністративного та трудового права. Те ж можна сказати і про правовідносини 3 майнового та продовольчого забезпечення. Що стосується правовідносин із соціально-побутового забезпечення, то вони тяжіють до цивільного права та права соціального забезпечення. Другу групу правовідносин щодо соціального захисту співробітників правоохоронних органів складають правовідносини 3 надання виплат і компенсацій співробітникам, які звільняються. Ці правовідносини $€$ адміністративними i трудовими. Неоднорідними за галузевою належністю $є$ і правовідносини третьої групи, які виникають у зв'язку з настанням соціальних випадків. Особливістю правовідносин 3 надання окремих заходів соціального захисту співробітників правоохоронних органів $€$ його тісніший зв'язок зі службовими (адміністративно правовими) відносинами, трудовими правовідносинами і правовідносинами із соціального захисту звичайних працівників. Цьому сприяє i те, що заходи соціального захисту співробітникам надають, як правило, ті правоохоронні органи, де вони проходять або проходили службу, і те, що нормативне регулювання цих відносин здійснюється галузевими нормативними актами правоохоронних органів. Пенсійне забезпечення і медичне обслуговування, соціальне обслуговування і соціальна підтримка, забезпечення соціальною допомогою регулюються нормами права соціального забезпечення, а відшкодування шкоди, заподіяної життю або здоров'ю працівників правоохоронних органів, нормами цивільного права.

У даній статmі про «Поняття соитільного захисту співробітників правоохоронних органів» автором було проаналізовано законодавство України та наукову літературу. Питання соціального захисту зумовлено об'єктивною потребою суспільства в ефективній системі забезпечення правопорядку, здатної гарантувати захист особистості, суспільства $i$ держави від злочинних посягань. Правоохоронні органи відіграють важливу роль у механізмі сучасної держави. Від ефективності їх діяльності багато в чому залежать рівень законності $і$ правопорядку в країні, безпека громадян, ступінь захисту їх прав та законних інтересів. У свою чергу, ефективність діяльності правоохоронних органів перебувае в прямій залежності від рівня соціального захисту ї працівників і иленів сімей співробітників. Однак як показує статистика, в даний час рівень соціального захисту працівників правоохоронних органів та членів їх сімей ще далекий від необхідного.

Специифіка правоохоронної служби, в тому числі обмеження на службі, вимагає забезпечення співробітників не тільки грошовим утриманням. Важливе значення мають охорона здоров'я, в тому числі медична допомога, медикаментозне забезпечення, санаторно-курортне лікування та відпочинок працівників $i$ членів їх сімей, утримання дітей співробітників у дитячих дошкільних установах, соціально-побутове забезпечення співробітників та їх сімей, пенсійне забезпечення, інші заходи соціальної захисту. Усе сказане вище зумовило актуальність теми цієї статті $i$ визначило ї вибір.

У нормативних правових актах i науковій літературі нерідко вживається словосполучення «соціальні гарантї̈. Це має місие як у найменуванні деяких нормативних правових актів, так $i$ в їх утриманні. Однак легального визначення поняття социіальни гарантій досі немає. Водночас $\epsilon$ нагальна необхідність дослідити ије поняття. Таке поняття є загальним $і$ охоплюе всі гарантіі, неза- 
лежно від їх змісту. У комплексі вони створюють можливості для здійснення громадянами своїх прав i виконання обов'язків. Існуе необхідність у класифікації гарантій із muх чи інших підстав. Якщо взяти за основу різні аспекти стану громадянина в суспільстві (економічний, політичний, соціальний, правовий), то можна виділити відповідні їм гарантї̈.

Ключові слова: правоохоронні органи, соціальний захист, соціальні гарантії, державні службовці, забезпечення.

\section{Aloshyn V. Concept of social protection of law enforcement officers}

In this article on the "Concept of social protection of law enforcement officers" the author analyzed the legislation of Ukraine and the scientific literature. The issue of social protection is due to the objective need of society in an effective system of law and order, able to guarantee the protection of the individual, society and the state from criminal encroachment. Law enforcement agencies play an important role in the mechanism of the modern state. The level of law and order in the country, the safety of citizens, the degree of protection of their rights and legitimate interests largely depend on the effectiveness of their activities. In turn, the effectiveness of law enforcement agencies is directly dependent on the level of social protection of their employees and family members of employees. However, statistics show that at present the level of social protection of law enforcement officers and their families is still far from necessary. The specifics of the law enforcement service, including restrictions on service, require providing employees not only with money. Important are health care, including medical care, medical care, spa treatment and recreation of employees and their families, maintenance of children of employees in preschool institutions, social and household support of employees and their families, pensions, others social protection measures. All the above determined the relevance of the topic of this article and determined its choice. In normative legal acts and scientific literature the phrase "social guarantees" is often used. This is the case both in the title of some normative legal acts and in their content. However, there is still no legal definition of social guarantees. This concept is general and covers all warranties, regardless of their content. Together, they create opportunities for citizens to exercise their rights and responsibilities. At the same time, there is a need to classify guarantees for one reason or another. If we take as a basis various aspects of the state of the citizen in society, we can identify the appropriate guarantees.

Key words: law enforcement agencies, social protection, social guarantees, civil servants, provision.

\section{Література}

1. Гетьманцева Н.Д. Право соиіального забезпечення: методичні рекомендації для студентів юридичного факультету Чернівці : Рута, 2003. С. 5-6.

2. Право соииального обеспечения учебник / под ред. К.Н. Гусова. Москва: ПВОЮЛ, 2001.

3. Конституція України : Закон України від 28.06.1996 № 254к/96. Відомості Верховної Ради України. 1996. № 30 (23.07.96). Cm. 141.

4. Конституції України : коменmap під. ред. В.Ф. Опришка. Київ, 1996. C. $58-61$.

5. Про державний захист працівників суду $i$ правоохоронних органів : Закон України від 23.12.93 № 3781. Відомості Верховної Ради України. 1994. № 11 (15.03.94). Cm. 50 .

6. Про основи національної безпеки України : Закон України від 26.09.2003 № 964-VI. Відомості Верховної Ради України. 2003. № 39. Сm. 351. 


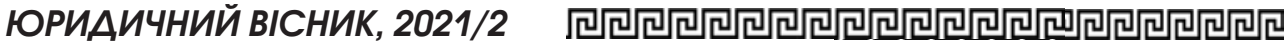

7. Г. Гончарова, В. Жернаков, С. Прилипко. Підручник з пенсійного забезпечення $є$, але чи є пенсійне право? Право України. 1998. № 12. С. 138-139.

8. Мачульская Е.Е. Право социиального обеспечення : учебн. пособие для вузов. 3-е изд., перераб. и доп. Москва: ЗАО «Книжныймир», 2001.

9. Захарова О.С., Карабань В.Я., Ковальський В.С. Суд, правоохоронні та правозахисні органи України : підручник. Київ : Юрінком Інтер, 2004. 376 с.

10. Судові та правоохоронні органи України : підручник / під. ред. проф. О.М. Бандурки. Харків : Ун-m внутр. дел, 1999. $350 \mathrm{c}$

11. Чувилев А.А. Правоохранительные органы : учебное пособие. Москва : Юриспрудениия, 2000. 176 с.

12. Сирота И.М. Право социального обеспечения в Украине : учебник. Харьков : Одиссей, 2000.

13. Доброхотова Е.Н., Филлипова М.В., Янтураева М.А. Советское право сочіального обеспечения. Санкт-Петербург : Изд. С.-Петербург. ун-та,1992. С. 5-6.

14. Болотіна H. Концепція кодифiкації законодавства України про соціальне забезпечення. Право України. 1996. № 7. C. 51-52.

15. Право соціального обеспечения : практикум. Нормативные акты. Образиь документов / Под ред. Э. Г. Тучковой. Москва: Новый юрист, 1997.
16. Чутчева О. Право на соииальную зашиту: вопросы теории. Підприємництво, господарство $і$ право. 2002. № 8. C. 62-64.

17. Клемпарський М.м. Співвідношення термінів «соціальний захист» та «соціальне забезпечення» в законодавстві України. Право і безпека. № 2(3). С. 92-95.

18. Приходько С. Держава і соціальний захист громадян. Право України. 1999. № 9. C. 25.

19. Панасюк О.T. Про зміст поняття «соціальний захист». Бюлетень Міністерства юстииї України. 2003. № 12. С. 77.

20. Сташків Б.І. Право людини на соціальне забезпечення та його реалізаиія в Україні. Захист соиіальних прав людини $i$ громадянина в Україні: проблеми юридичного забезпечення : матеріали науково-практичної конференціі 30 січня 2003 р. Київ, 2003. С. 40.

21. Болотіна Н. Право людини на соціальне забезпечення в Україні : проблеми термінів і понять. Право України. 2000. № 4. C. 35-40.

22. Кісіль О.Ю. Загальні підходи до розуміння категорії «соиіальне забезпечення». Право і безпека. 2011. № 5(42). URL:http:werw.nbuv.ua/portal/soc_gom / pib/2011_5PB-5/PB-5_41.pdf.

23. Устинов С.О. Співвідношення термінів «соціальний захист» та «соціальне забезпечення» в законодавстві України. Юридична наука і практика. № 2. 2011. C. 90-95. 